\title{
Effect of parameters of production process of photocatalytic coatings on bactericidal property
}

\author{
Marina Ivanovna Vasilenko \\ Belgorod State Technological University named after \\ V. G. Shukhov \\ BSTU named after V.G. Shoukhov \\ Belgorod, Russia \\ vasilemn@mail.ru
}

Yury Konstantinovich Rubanov

Belgorod State Technological University named after V. G. Shukhov

BSTU named after V.G. Shoukhov

Belgorod, Russia

yrubanov@yandex.ru

\author{
Elena Nikolayevna Goncharova \\ Belgorod State Technological University named after \\ V. G. Shukhoy \\ BSTU named after V.G. Shoukhov \\ Belgorod, Russia \\ eleng59@mail.ru
}

\author{
Yulia Egorovna Tokach \\ Belgorod State Technological University named after \\ V. G. Shukhov \\ BSTU named after V.G. Shoukhov \\ Belgorod, Russia \\ tokach@bk.ru
}

\author{
Vladimir Mikhailovich Nartsev \\ Belgorod State Technological University named after \\ V. G. Shukhov \\ BSTU named after V.G. Shoukhov \\ Belgorod, Russia
}

\begin{abstract}
The paper presents the results of researching the influence of the mode of creating photocatalytic coatings of glass substrates by the method of reactive magnetron deposition on their bactericidal properties. Tatanium dioxide $\left(\mathrm{TiO}_{2}\right)$ is in the basis of used film photocatalytic coatings. When depositing coatings, such parameters were varied as work pressure in the chamber, volume fraction of reactionary gas $\left(\mathrm{O}_{2}\right)$, durability of deposition, a distance "magnetron-sample", average current of discharge, etc. Bacterial culture Escherichia coli was used as a test-object. The change of the indentified parameters in a certain interval allowed specifying the mode of deposition of photocatalytic film, by which bactericidal effect is achieved. In real conditions of the environment, experiments on revealing selfantiseptic ability of the obtained coatings, confirming the reduction of surface contamination in the presence of film, were conducted.
\end{abstract}

Keywords - photocatalytic films, titanium dioxide, deposition mode, bactericidal properties, self-antiseptic ability.

\section{INTRODUCTION}

At present, to maintain sanitury-hugienic requirements for the quality of environment, photocatalytic systems are widely used. Among various coatings, providing biocidity of items and surfaces, nanostructural films, based on oxides and titanium oxynitrides, are of particular importance $[1,2]$.
For a long time, titanium dioxide was used as a white pigment and as a cosmetic component. However, in the past decades, after thourough analysis of photocatalytic properties of this compound, directions of practical application of the mineral have acquired vast scale. The major part of them is oriented to the processes of removing organic and nonorganic contaminants of air and water, to the necessary partial oxidation of organic compounds in certain processes, as well as disinfection of the medium $[3,6]$.

Thin films of titanium dioxide can cover different types of construction materials, used for finishing both inner and outer surfaces, bell glass on tunnel lamps of highways and lamp caps of outdoor lighting in airports that are darkening quickly because of transport exhaust gases, aluminium decorative panels. It is possible to modernize canvas materials for tents, paper screens and paper blinds. In the majority of cases, material surfaces will possess such functions as self-cleaning, the cleaning of contacting media, elimination of pathogenic microflora. Products of photocatalytic reactions can be naturally washed off by rain water or, if necessary, washed off forcibly, maintaining cleanness of surface.

The enumerated advantages and possibilities of wide application of photocatalytic coatings stimulate interest and necessity of conducting studies within creation of different 
self-cleaning and bio stable materials, including those intended for construction purposes, because of progressing processes of biodestruction of buildings and constructions [8-10].

Owing to intensive oxidation properties of titanium dioxide, films manifest biocidal properties, destructing cell walls and membranes, violating biochemical reactions of bacteria cells, viruses of microfungi $[5,7]$.

Photocatalytic disinfection using irradiated titanium dioxide is effective for killing a large spectrum of microorganisms and cell formations. The process is applicable to the use in water and air media and can be used in vivo. Mechanisms, by means of which cells can be damaged, have not been revealed completely. Effects that emerged because of appearance of active forms of oxygen on the irradiated surfaces of $\mathrm{TiO}_{2}$, are connected with both attack of the cell from outside and generation of oxygen inside the cell, if finest $\mathrm{TiO}_{2}$ particles penetrate into the cell. Effectiveness of the biodegradation process depends on a number of factors: reactor configuration, light source, $\mathrm{TiO}_{2}$ type, components of the medium and used organisms.

The photocatalytic method includes several ways of influence on microorganisms, which can work simultaneously - adsorption of titanium dioxide on the surface of cell walls with subsequent penetration inside; formation in both cases of active forms of oxygen, manifesting oxidation aggression with respect to the cell components, as well as destructive actions of other direct and roundabout photochemical processes.

Photocatalysis is a natural phenomenon, in which a substance, called as a photocatalyst, accelerates the speed of chemical reactions under the influence of light (natural and artificial). Using light energy, the photocatalyst generates transformation of water and oxygen from the ambient air into highly reactive free radicals, destroying organic substances or transforming harmful compounds into completely harmless during oxidation-reduction reactions.

The formed hydroxyl and superoxide can destruct not only organic molecules, but also bacteria, viruses, mold, algae, microscopic fungi, pollen of dusty ticks; destruct odours of volatile organic compounds. In contrast to traditionally used chemical substances (chlorine- and phenol-containing preparations, substances based on derived guanidines) and ultraviolet irradiation on the photocatalytically active coatings based on titanium oxide $\left(\mathrm{TiO}_{2}\right)$, rapid non-reagent elimination of microorganisms occurs.

One of the problems on the way of creation of effective photocatalysts with a long-term service is reliable detection of their activity since photoreduction, adsorption and photo adsorption, concentration and availability of catalytic centres, as well as many other factors, influence the process of photocatalytic decomposition. Owing to that, the decomposition rates of structurally different moleculecontaminants on the same sample of the photocatalyst can differ considerably [11].

Properties of photocatalytic films (activity, reaction capability, etc.) depend on the method of obtainment and are determined by the phase composition, the structure and the size of film pores. Effectiveness of division of photo-injected charges influences the photocatalytic activity during absorption of light quantum in the fundamental absorption band of semiconductor $\left(\mathrm{TiO}_{2}\right)$ and interphase transfer of the electron on the interface " $\mathrm{TiO}_{2}$ /electrolyte". The structure and the thickness of $\mathrm{TiO}_{2}$ film determine its sorption capability, which is especially important during sorption of proteins, $\mathrm{TiO}_{2}$ modification by biocatalysts, as well as for effectiveness of electron exchange between biocatalyst and $\mathrm{TiO}_{2}$. For a number of practical applications, optical quality of the film (low light scattering and transparency of not less than 90\%) and mechanical strength are of significant importance.

By now, despite a considerable number publications, devoted to coatings based on titanium dioxide [12-17], there is not enough information on recording and influence of the whole variety of parameters of the process of magnetron deposition of $\mathrm{TiO}_{2}$ coatings on their photocatalytic activity with respect to different substances and organisms.

\section{MATERIALS, CONDITIONS AND METHODS}

Dioxide-titanium coatings precipitated on samples of glass with the size of $(50 \pm 2) \times(50 \pm 2) \mathrm{mm} \times \mathrm{mm}, 4 \mathrm{~m}$ thick, containing (mass \%): $72.7-\mathrm{SiO}_{2}, 13.3-\mathrm{Na}_{2} \mathrm{O}, 8.8-\mathrm{CaO}, 3.7$ - $\mathrm{MgO}, 1.0-\mathrm{Al}_{2} \mathrm{O}_{3}, 0.08-\mathrm{Fe}_{2} \mathrm{O}_{3}, 0.3-\mathrm{SO}_{3}$, by the method of reactive magnetron deposition on the plant Quadra-500TM (RPC "Elan-Praktik"). Glasses before deposition were subjected to ultrasonic cleaning sequentially in tetrachloride methane, acetone and alcohol with subsequent treatment in glow discharge [12].

During experiments, the following parameters of the process of magnetron deposition on glass titanium dioxide substrates were varied in different combinations:

- $\quad$ working pressure $-0.22 \mathrm{~Pa}$ and $0.4 \mathrm{~Pa}$;

- volume fraction of reactionary gas $\left(\mathrm{O}_{2}\right)-15 \%, 20 \%$, $17.5 \%$;

- duration of deposition - 30 min and $40 \mathrm{~min}$;

- distance between the magnetron and the sample - 70 $\mathrm{mm}$ and $140 \mathrm{~mm}$;

- current strength - 3.0 A and 5.6 A.

The thickness of film coatings was determined by means of spectral ellipsometer "Uvisel 2" and the software "DeltaPsi2"[12].

Samples of three types were subjected to tests, the modes of deposition of dioxide titanium films are given in Table 1.

TABLE I. PROCESS-DEPENDENT PARAMETERS OF DEPOSITION OF DIOXIDE TATANIUM FILMS ON GLASS SAMPLES

\begin{tabular}{|l|l|c|c|c|}
\hline № & \multicolumn{1}{|c|}{ Parameters } & Type 1 & Type 2 & Type 3 \\
\hline 1 & Working pressure, Pa & 0.22 & 0.22 & 0.4 \\
\hline 2 & Volume fraction $\mathrm{O}_{2}, \%$ & 20 & 15 & 17.5 \\
\hline 3 & Current, A & 3.0 & 5.6 & 5.6 \\
\hline 4 & Deposition duration, min & 30 & 30 & 40 \\
\hline 5 & $\begin{array}{l}\text { Distance "magnetron- } \\
\text { sample", mm }\end{array}$ & 140 & 70 & 70 \\
\hline 6 & $\begin{array}{l}\text { Thickness of obtained } \\
\text { films, nm }\end{array}$ & 59 & 128 & 79 \\
\hline
\end{tabular}


Bactericidal action of film coatings with respect to Escherichia coli was determined in accordance with methodology ISO 27447:2009 (E) "Fine ceramics (advanced ceramics, advanced technical ceramics) - Test method for antibacterial activity of semiconducting photocatalytic materials" [18]. This standard is applied for testing antibacterial activity of photocatalytic ceramics and other materials, obtained by adding the photocatalyst or deposition of photocatalytic coating.

The method is used for estimating antibacterial activity of photocatalytic materials when the sample contacts bacteria and during UV irradiation. Irradiation time is $12 \mathrm{~h}$, wavelength is $365 \mathrm{~nm}$, surface density of radiant flux is $0.1 \mathrm{~mW} / \mathrm{cm}^{2}$. To localise bacterial suspension on the surface of flat materials under study, coating film is used. In Petri dish, there is a sample, on which a drop of bacterial suspension is deposited. Then the coating film is placed into suspension, Petri dish is covered with glass for moisture retention; after that, irradiation takes place.

After UV processing, bacteria are washed off the sample and the coating film. In the washed-off suspension, the number of viable bacteria is measured by the calculation method. The increased bacterial clupms were calculated using an automatic clump counter "SCAN color".

For experiments on self-sterilization, coatings were precipitated on substrates in vacuum plant UniCoat 200 with a dual unbalanced magnetron system and pulse current, in the mode, presented in Table 2 .

TABLE II. MODE OF COATING DEPOSITION IN PLANT "UNICOAT"

\begin{tabular}{|c|c|c|}
\hline Stage & Parameter & Parameter value \\
\hline \multirow{5}{*}{ Ion-beam cleaning } & Duration & $10 \mathrm{~min}$ \\
\hline & Argon pressure & $0.093 \mathrm{~Pa}$ \\
\hline & Discharge voltage & $1800 \mathrm{~V}$ \\
\hline & Discharge current & $120 \mathrm{~mA}$ \\
\hline & Rate of discharge pulses & $15 \mathrm{kHz}$ \\
\hline \multirow{2}{*}{ Setting pressure } & Duration & $2 \min$ \\
\hline & Argon pressure & $0.22 \mathrm{~Pa}$ \\
\hline \multirow{9}{*}{$\begin{array}{l}\text { Coating } \\
\text { deposition }\end{array}$} & Duration & $30 \mathrm{~min}$ \\
\hline & Total pressure & $0.22 \mathrm{~Pa}$ \\
\hline & Oxygen fraction & 15, vol. $\%$ \\
\hline & Average discharge current & $3.26, \mathrm{~A}$ \\
\hline & $\begin{array}{l}\text { Average discharge } \\
\text { pressure }\end{array}$ & $501, \mathrm{~V}$ \\
\hline & Discharge pulse rate & $15 \mathrm{kH}$ \\
\hline & $\begin{array}{l}\text { Distance from magnetrons } \\
\text { to sample }\end{array}$ & $10 \mathrm{~cm}$ \\
\hline & $\begin{array}{l}\text { Rotation frequency of } \\
\text { carrousel with samples }\end{array}$ & $20 \mathrm{rev} / \mathrm{min}$ \\
\hline & Area of 2 targets & $287.12 \mathrm{~cm}^{2}$ \\
\hline Cooling & Duration & $1 \mathrm{~min}$ \\
\hline
\end{tabular}

\begin{tabular}{|l|c|c|}
\hline Stage & Parameter & Parameter value \\
\hline & Total pressure & $0.22 \mathrm{~Pa}$ \\
\hline & Oxygen fraction & $20 \mathrm{vol} . \%$ \\
\hline Cooling in argon & Duration & $10 \mathrm{~min}$ \\
\hline & Argon pressure & $0.22 \mathrm{~Pa}$ \\
\hline
\end{tabular}

When revealing self-antiseptic ability of coatings, tests were conduted in one of the lecture halls of the university with an area of $15 \mathrm{~m}^{2}$, a volume of $45 \mathrm{~m}^{3}$ and a daily loading of 600 people. Ventilation in the lecture hall was forced influx-andextract. For tests, two samples of float-glass (grade M1) were used. One sample was with photocatalytic coatings and a material sample without coating was taken as a control sample.

All samples were horizontally attached to each other and held open during 11 hours. The obtained microbial suspension based on the washing-off from the glass surface was dissolved up to $10^{-5}$ by physiological solution, whereupon it was sown onto the agarised nutrient medium and incubated during 48 hours at $37.0^{\circ} \mathrm{C}$. Further, the number of grown clumps of microorganisms was calculated with subsequent calculation of the surface ability for self-sterilization $\left(\mathrm{R}_{\mathrm{L}}\right)$ by the formula:

$$
\mathrm{R}_{\mathrm{L}}=\lg \left(\mathrm{B}_{\mathrm{L}} / \mathrm{C}_{\mathrm{L}}\right),
$$

where $B_{L}$ - average number of viable microorganisms on samples without photocatalyst; $\mathrm{C}_{\mathrm{L}}$ - average number of viable microorganisms on samples with photocatalyst.

\section{RESULTS AND DISCUSSION}

According to the used method of estimation of bactericidal action of photocatalytic coatings, the bacterial suspension, washed off the samples, was subjected to sowing onto the solid medium with dissolutions of $10^{-1}, 10^{-2}, 10^{-3}, 10^{-4}$. However, in the first three cases, the number of grown clumps was so big that it was impossible to assess the difference when transiting from one variant to another. Therefore, Petri dishes with sowing of the wash-off suspensions, obtained with the dissolution of $10^{-4}$, where the number of clumps was less than 300 , were subjected to a more detailed analysis.

Results of development of the bacterial cells washed off the surface of photocatalytic materials on the solid nutrient medium are presented in photographs in Figure 1. Results of development of bacterial cells of the wash-off from the photocatalytic materials' surface on the solid nutrient medium are presented in Figure 12.

It is necessary to note that the effect of suppressing the development of bacterial cells on photocatalysts' surfaces is noted both in the variants of storing materials with the deposited suspension in darkness and when storing under conditions of UV light influence (Figure 1). 

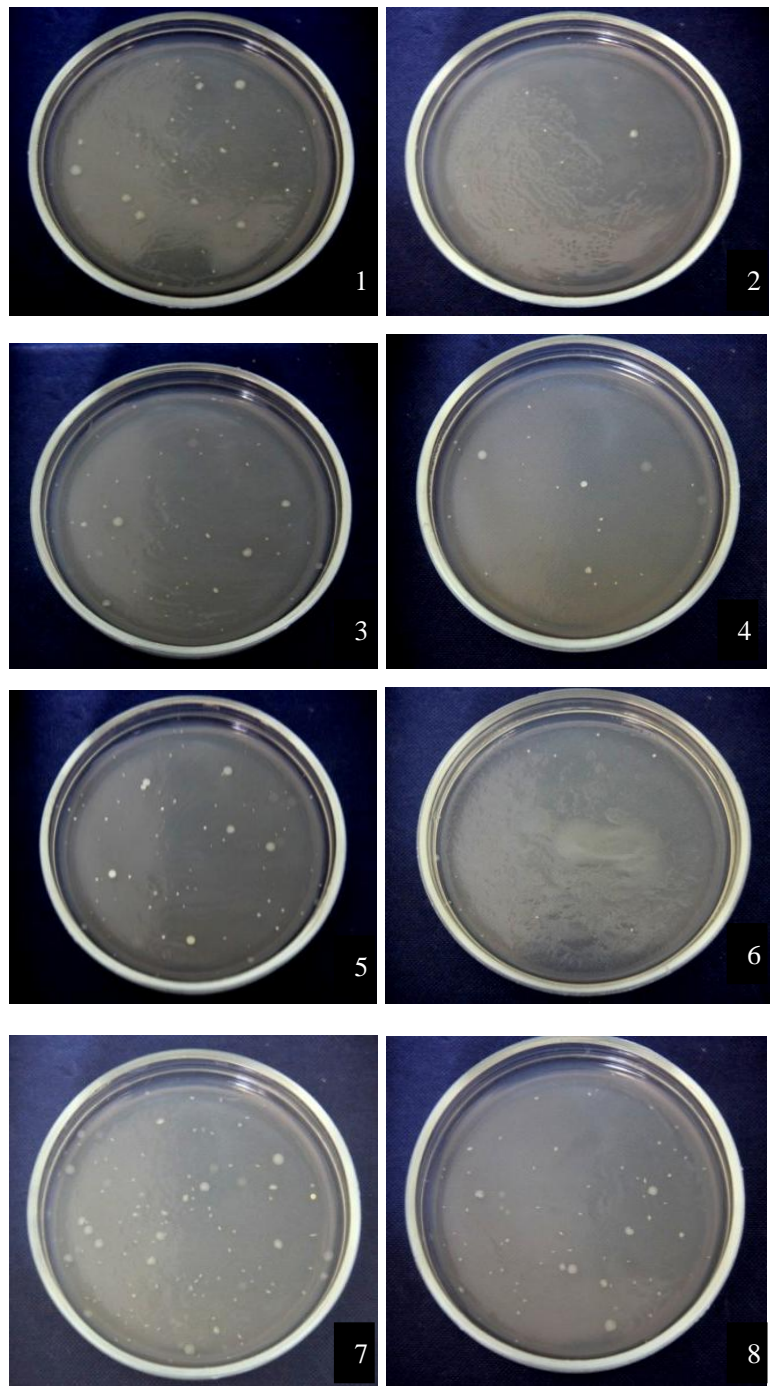

Fig. 1. Clumps of Escherichia coli on solid nutrient medium, sown from surfaces of studied samples with photocatalytic coating (kind $1-1,2$; kind 2 $-3,4$; kind $3-5,6)$ and from surface of samples without coatings $(7,8)$ after storage in darkness (left column) and in UV (right column).

As photographs, presented in Figure 1, show, the effect of suppression of bacterial cells' development on the surfaces of photocatalysts is evident. The reduction of the number of viable cells on samples, both in cases of storing materials with deposited suspension in darkness and when storing them under conditions of UV light influence, with clear advantage of the latter conditions, is noted.

With additional influence of ultraviolet irradiation, the bacterial effect increases. $\mathrm{TiO}_{2}$, contacting with cell suspension during UV influence, strengthens inactivation of microorganisms, probably, because of arising raptures of the cell wall and intensive transport transfer. However, accurate mechanisms, underlying the influence of photocatalytic reactions of $\mathrm{TiO}_{2}$ on living microbial cells, are studied insufficiently.

Results of the comparative complex influence of processdependent parameters of obtaining vitreous products with photocatalytic coating on the degree of their bactericidal activity are presented in Table 3 .
Antibacterial activity of the studied photocatalysts after UV irradiation was assesses by means of the conditional index $\mathrm{R}[18]$.

TABLE III. BACTERICIDAL PROPERTIES OF DIOXIDE FILMS OBTAINED IN DIFFERENT MODES OF THEIR DEPOSITION

\begin{tabular}{|l|l|c|c|c|}
\hline \multirow{2}{*}{$№$} & \multicolumn{1}{|c|}{ Indicator } & \multicolumn{3}{|c|}{ Variants of film coatings } \\
\cline { 3 - 5 } 1 & \multicolumn{3}{|c|}{ Kind 1 } & \multicolumn{2}{|c|}{ Kind 2 } & Kind 3 \\
\hline \multirow{2}{*}{2} & $\begin{array}{l}\text { Average number of viable } \\
\text { bacteria on samples without } \\
\text { coating }\end{array}$ & \multicolumn{3}{|c|}{} \\
\hline \multirow{2}{*}{3} & $\begin{array}{l}\text { Average number of viable } \\
\text { bacteria on samples with } \\
\text { coating }\end{array}$ & $1.5 \cdot 10^{5}$ & $4.05 \cdot 10^{5}$ & $1.5 \cdot 10^{5}$ \\
\hline \multirow{2}{*}{3} & $\begin{array}{l}\text { Assessment of antibacterial } \\
\text { activity of photocatalysts } \\
\text { after UV irradiation, } \mathrm{R}_{0,1}\end{array}$ & 0.59 & 0.16 & 0.59 \\
\hline
\end{tabular}

As data showed, the greatest destructive ability belonged to the products with the photocatalytic coating, obtained under conditions of $20 \%$ of oxygen content at a distance "Magnetron-sample" of $140 \mathrm{~mm}$ and the duration of coating deposition of 30 minutes (kind 1) and with oxygen concentration in the reaction chamber of $17.5 \%$, when the distance "magnetron-sample" was $70 \mathrm{~mm}$, and the duration of coating deposition was 40 minutes (kind 3). The number of bacterial cells Escherichia coli reduces in these cases 4 times as compared to the substrate without coating, whereas in variant 2 , there is a weaker effect -1.44 times.

The calculated index of antibacterial activity of photocatalysts with UV irradiation $(\mathrm{R})$ had the greatest value (0.59) for the first and third variants of coatings whereas for the second -0.16 .

On the same samples, as results of preliminary analyses showed, reactions of oxidation of organic substances proceeded most effectively, reducing the amount of oleic acid by $50 \%$ and the content of methylene-blue in the medium by $20 \%$.

The presented results are confirmation of the fact that an increase of photocatalytic activity does not always happen with the growth of the coating thickness. In this case, low bacterial activity $(0,16)$ was observed in photocatalysts with the greatest thickness of the film equal to $128 \mathrm{~nm}$ (compared to $59 \mathrm{~nm}$ and $79 \mathrm{~nm}$ in variants with higher bacterial activity). The reason for that can be defects, microcrystal sizes, pores and other structural changes, occurring during precipitation of coatings with the magnetronic method.

One of the interesting and promising directions of practical application of photocatalysis is imparting the ability for selfdecontamination to finishing materials, for instance, for medical establishments, premises of public buildings, where mass public gatherings are observed $[19,20]$.

The results of microbiological tests of glasses with photocatalytic coatings in real conditions of lecture halls are presented in Table 4. 
TABLE IV. RESULTS OF MICROBIOLOGICAL TESTS OF SAMPLES

\begin{tabular}{|c|c|c|c|c|}
\hline \multirow{3}{*}{$\begin{array}{l}\text { Dilution } \\
\text { factor }\end{array}$} & \multicolumn{4}{|c|}{$\begin{array}{c}\text { Number of microorganisms' clumps, sown from } \\
\text { samples }\end{array}$} \\
\hline & \multicolumn{2}{|c|}{$\begin{array}{l}\text { With photocatalytic } \\
\text { coatings }\end{array}$} & \multicolumn{2}{|c|}{$\begin{array}{l}\text { Without photocatalytic } \\
\text { coatings }\end{array}$} \\
\hline & Sample 1 & Sample 2 & Sample 1 & Sample 2 \\
\hline 1 & 59 & 27 & $>100$ & $>100$ \\
\hline $10^{1}$ & 5 & 3 & $>100$ & $>100$ \\
\hline $10^{2}$ & 1 & 1 & 24 & 21 \\
\hline $10^{3}$ & 0 & 1 & 3 & 2 \\
\hline $10^{4}$ & 1 & 0 & 1 & 1 \\
\hline $10^{5}$ & 0 & 0 & 1 & 0 \\
\hline \multicolumn{5}{|c|}{ Number of cells } \\
\hline cells $/ 10 \mathrm{ml}$ & 55 & 29 & 2700 & 2050 \\
\hline $\begin{array}{l}\text { Average } \\
\text { number of } \\
\text { viable cells }\end{array}$ & \multicolumn{2}{|c|}{41.5} & \multicolumn{2}{|c|}{2375} \\
\hline
\end{tabular}

Estimated parameter $\mathrm{R}_{\mathrm{L}}$, determining the ability of coatings for self-sterilization, made up 1,76, i.e. the concentration of bacteria and molds on samples' surface with photocatalytic coating is almost by two orders less than those on the surface, not possessing photocatalytic properties.

It should be noted that results of microbiological tests include generalised data on bacteria and spores of molds. This can influence parameter $\mathrm{R}_{\mathrm{L}}$ since during incubation, some molds are able to stop the growth of bacterial, which appeared in immediate proximity to the fungus colony, that is, to influence the bacterial activity indicators.

The necessity of creating universal photocatalytic materials will require, on the one hand, the extension of a set of used test-cultures, taking into account the specifics of protective mechanisms of microbial cells, and, on the other - further search for modes, providing a combination of peaks of activity for different microorganisms.

\section{CONCLUSIONS}

The use of specific photocatalytic coatings provides biocidity of products' surface, determining such property of modern materials as an ability for self-decontamination. One of the promising directions in this field is creation of photocatalytically active coatings based on $\mathrm{TiO}_{2}$, on the surface of which reagentless elimination of microorganisms takes place.

The comparative characteristic of effectiveness of glass samples with photocatalytic coating, obtained in different operating practices of deposition of the film, allowed detecting the best products, on the surface of which the processes of bacteria elimination proceeded most effectively.
However, the proposed variants of depositing the photocatalytic film on constructional products require additional studies, as experimental data showed.

To develop the most effective photocatalyst with the function of bactericidal action, the search for modes, providing a combination of activity peaks for different groups of substances and kinds of microorganisms, is necessary. Modern scientific knowledge in the field of the variety of mechanisms of influence of photocatalytic processes on fungi cells, taking into account the specifics of their protective mechanisms, will require spreading the spectrum of used test-cultures.

\section{Acknowledgment}

The work is realized in the framework of the Program of flagship university development on the base of Belgorod State Technological University named after V.G. Shoukhov, using equipment of the High Technology Center at BSTU named after V.G. Shoukhov..

\section{References}

[1] N. Huang, P. Yanga, Y.X. and Leng, et.al., "Hemocompatibility of titanium oxide films,". Biomaterials, vol.24, pp. 2177-2187, 2003.

[2] H.A. Foster, I.B. Ditta, S. Varghese, A. Steele, "Photocatalytic disinfection using titanium dioxide: spectrum and mechanism of antimicrobial activity," Appl.Microbiol. Biotechnol, vol. 90, pp. 1847 1868, 2011

[3] D.M. Blake, Bibliography of Work on the Photocatalytic Removal of Hazardous Compounds from Water and Air Update, NREL/TP-57026797, August 1999.

[4] L. Sikong, B. Kongreong, D. Kantachote, W. Sutthisripok, "Inactivation of salmonella typhi using $\mathrm{Fe}^{3+}$ doped $\mathrm{TiO}_{2} / \mathrm{SnO}_{2}$ photocatalytic powders and films," J. Nano Res. 12, pp.89-97, 2010.

[5] U. Joost et al., "Photocatalytic antibacterial activity of nano-TiO2 (anatase)-based thin films: effects on Escherichia coli cells and fatty acids," Journal of Photochemistry and Photobiology B: Biology, vol. 142, 178-185, 2015.

[6] O.K. Dalrymple, E. Stefanakos, M.A. Trotz, D.Y. Goswami, "A review of the mechanisms and modeling of photocatalytic disinfection," Appl. Catal. B-Environ. vol. 98, pp. 27-38, 2010.

[7] L. Rizzo, A.D. Sala, A. Fiorentino, G.L. Puma, 'Disinfection of urban wastewater by solar driven and UV lamp $-\mathrm{TiO}_{2}$ photocatalysis: effect on a multi drug resistant Escherichia coli strain," Water Res, vol. 53, pp. 145-152, 2014.

[8] M.I. Vasilenko, E.N. Goncharova, "Microbiological peculiarities of process of concrete surface damages", Fundamental studies, vol. 4, pp. 886-891, 2013.

[9] Evtushenko E.I., Lesovik V.S. "Towards stabilisation of properties of constructional materials", Herald of department of constructional sciences, vol.9, pp. 267-271, 2005.

[10] A.V. Savin, V.S. Lesovik, N.I. Alfimova, "Towards problem of corossion resistance of reinforced concrete" Herald of Belgorod State Technological University named after Shukhov V.G., vol.2, pp. 7-12, 2013.

[11] J. Ryu, W. Choi, "Substrate-Specific Photocatalytic Activities of $\mathrm{TiO}_{2}$ and Multiactivity Test for Water Treatment. Application," Environmental Science and Technology, vol.42, pp. 294-300, 2008.

[12] V.M. Nartsev, N.V. Osipenko, S.V. Zaitsev, M.I. Vasilenko, E.N Goncharova, V.S. Vashchilin, E.I. Evtushenko, "Research of optical properties and assessment of photocatalytic activity of $\mathrm{TiO}_{\mathrm{X}}$-coatings, synthesised by method of magnetronic precipitation", Refractories and technical ceramics, vol. 10, pp. 3-9, 2013.

[13] I.V. Blonskiy, A.A. Goncharov, Demchishin et al. "Research of optical charaeristics of cylinder gas discharge of magnetronic kind under 
conditions of titanium nitride film synthesis", Journal of engineering physics, 79, p. 7, 2009.

[14] T. Tölke, A. Kriltz, A. Rechtenbach, "The influence of pressure on the structure and the self-cleaning properties of sputter deposited $\mathrm{TiO}_{2}$ layers", Thin Solid Films, vol. 518, pp. 4242-4246, 2010.

[15] E.I. Evtushenko, V.M. Nartsev, S.V. Zaitsev, N.V. Osipenko, D.S Prokhorenkov, "Study of properties of $\mathrm{TiO}_{\mathrm{X}}$-coatings, formed with the use of vacuum-plasma technologies", Fundamental studies, vol. 11, No. 5, pp. 1195-1200, 2012

[16] M. Lilja, J. Forsgren, K. Welch, M. Astrand, H. Enqvist, M. Stromme, "Photocatalytic antimicrobial properties of surgical implant coatings of titanium dioxide deposited though cathodic arc evaporation," Biotechnol. Lett., vol.34, pp. 2299-2305, 2012.

[17] A.B. Panda, S.K. Mahapatra, P.K. Barhai, A.K. Das, I. Banerjee, "Understanding of gas phase deposition of reactive magnetron sputtered $\mathrm{TiO}_{2}$ thin films and its correlation with bactericidal efficiency," Appl. Surf. Sci. vol. 258, pp. 9824-9831, 2012.

[18] ISO 27447, "Fine ceramics (advanced ceramics, advanced technical ceramics), Test method for antibacterial activity of semiconducting photocatalytic materials", 2009 (E).

[19] T.-M. Tsai, H.-H. Chang, K.-C. Chang and oth. "A comparative study of the bactericidal effect of photocatalytic oxidation by $\mathrm{TiO} 2$ on antibioticresistant and antibiotic-sensitive bacteria,".Journal Chem Technol Biotechnol, vol. 85, 1642-1653, 2010.

[20] W. Sangchay, "Fe doped $\mathrm{TiO} 2$ thin films coated on glass fiber to inhibit bacterial of E. coli prepared by sol-gel method", Digest Journal of Nanomaterials and Biostructures, Vol. 9, No. 4, p. 1593 - 1601, October - December 2014. 